\title{
Relationship Between Corporate Social Responsibility Disclosure, Corporate Governance, And Tax Avoidance
}

\author{
Maria Natalia ${ }^{1}$, Verani Carolina ${ }^{2}$ and Joni ${ }^{3}$ \\ 1,2,3 Maranatha Christian University, Bandung, Indonesia \\ maria.natalia@eco.maranatha.edu
}

\begin{abstract}
This study aims to examine the effect of corporatesocial responsibility disclosure on tax avoidance with corporate governance as moderation variable. The disclosure of corporate social responsibility in this study is measured using performance indicators from Global Reporting Initiative (GRI) 4.1. The score of corporate governance is measured using ASEAN CG Scorecard, while tax avoidance is measured by Cash ETR. The sample in this study is a manufacturing company listed on the Indonesia Stock Exchange in 2018. This study refers to Lanis and Richardson (2012) which found that, the higher the disclosure of social responsibility, the lower the tax avoidance. This study also refers to Salhi et al. (2019) which found that, if corporate governance has been performed well, companies are less likely to do tax avoidance. The results of the study showed that corporate social responsibility and corporate governance had no effect on tax avoidance. Likewise, corporate governance cannot moderate the effect of corporate social responsibility on tax avoidance

Keywords: corporate social responsibility disclosure, corporate governance, tax avoidance, GRI, Asean CG Scorecard, Cash ETR
\end{abstract}

JEL $\quad:$ M41

DOI : : 10.24002/kinerja.v25i1.4198

Received : 02/03/2021 Reviewed: 03/04/2021 Final Version: 03/09/2021 


\section{INTRODUCTION}

Corporate social responsibility is a form of corporate responsibility to all stakeholders, while tax is a form of corporate social responsibility to stakeholders through the government. Thus, companies involved in tax avoidance are socially irresponsible companies (Lanis and Richardson, 2012). By avoiding taxes, companies can increase profitability and cash flow, but the tax reduction can affect support for the government in development and other social programs (Supriyadi, 2016).

Research of Hoi, et al. (2013) found that companies with irresponsible corporate social responsibility disclosures tend to practice tax avoidance aggressively. Meanwhile, according to Dharma and Noviari (2017), companies with responsible corporate social responsibility activities have a lower chance of getting involved in tax avoidance practices.

One of the important principles in implementing good corporate governance is the principle of transparency. If the company applies this principle, the company will provide information not only as required by the provisions, but also other relevant information required by shareholders and stakeholders. With transparency and openness, external parties can access important company information, including tax information (Wahyudi, 2014).

Research of Minnick (2010) found that corporate governance affects tax avoidance. Corporate governance plays an important role in controlling the consequences of agency problems in tax avoidance practices, where this practice opens opportunities for managers to be opportunistic for short-term profit goals which are likely to harm shareholders in the long term.

Based on the description above, the researchers are interested in conducting research on the effect of corporate social responsibility disclosure on tax avoidance, with corporate governance as moderation variable. This study refers to the research of Lanis and Richardson (2012) which found that the higher the disclosure of social responsibility, the lower the tax avoidance. This study also refers to the research of Salhi et al. (2019) who found that if corporate governance has been performed well, companies are less likely to do tax avoidance.

The difference between this study and previous studies is the use of corporate governance variable as moderating variable. The corporate governance score is measured using the ASEAN CG Scorecard. The implementation of the Asean CG Scorecard in Indonesia is still quite few, so that the Otoristas Jasa Keuangan (OJK) encourages the implementation of good corporate governance. The next difference is the sample. In this study, the samples used were manufacturing companies listed on the Indonesia Stock Exchange (IDX) during 2018. Manufacturing companies were used as samples, because there was a decrease in tax revenue in January 
2019. From this, it can be seen that manufacturing companies are indicated to have committed tax evasion which could harm state revenue.

\section{LITERATURE REVIEW}

\subsection{Legitimacy Theory}

The difference between company values and social values is often called the "legitimacy gap" which can affect the company's capabilities to continue its business activities. The company must identify the activities under its control and reassure the public related to company operating activities. This is done so that the company get legitimacy from the public which in the end will reduce the legitimacy gap.

According to Tarigan (2014), reporting of sustainability reports conducted by companies can reduce the legitimacy gap. In addition, disclosure of Corporate Social Responsibility can be a medium of communication between the company and the public, which is expected to improve the company's legitimacy, increase company profits in the future and ensure the company's going concern (Lindawati \& Puspita, 2015).

\subsection{Stakeholder Theory}

Freeman and McVea (2001) defined stakeholder as any group or individual who able to influence or be influenced by the achievement of organizational goals. Stakeholder theory strengthens the concept that companies are responsible not only to shareholders but also to stakeholders (Maulida \& Adam, 2012). According to Freeman (1984), the stakeholder theory identifies the generation of value as a central driver of every corporate, but it recognises that this value is to be shared by a group of stakeholders that includes not only shareholders and managers but all society that may have an interest in the firm operates. The theory is structured under two key questions: What is the firm's purpose? And what is management's responsibility to stakeholders? These questions direct executives to think about how kind of relationships they want and need to create with stakeholders in order to achieve their goals (Freeman, 2000).

The stakeholder theory is "managerial" in the sense that it addresses how managers perform their duties, and it is intimately connected to the practice of business, of value creation and trade (Laplume, Sonpar, \& Litz, 2008). Moreover, it explicitly recognizes that shareholders are important stakeholders; however, they are just one of myriad incumbents. Similarly, it recognizes that profits are a important dimension of the day-to-day activity of the firm, but profits and financial performance are one possible outcome of the process of value creation. 
According to Donaldson and Preston (1995), the theory can be examined from three different perspectives, namely, the descriptive, the instrumental and the normative perspectives. The descriptive perspective assumes an empirically oriented use of the theory to show how concepts correspond to reality. Theodoulidis et al. (2017) instrumental perspective relates to the use of the theory to show the connection between stakeholder management and multidimensional corporate performance. Third, the normative perspective is used to examine how stakeholders behave and the motivations underlying their actions.

Stakeholder Theory and then grew into organization theory (e.g. Donaldson \& Preston, 1995), business ethics (e.g. Phillips \& Reichart, 2000), social issues in management (e.g. Wood, 1991) and sustainable development (e.g. Sharma \& Henriques, 2005). Over the last few years, there has been a rise in its prominence, in a recent review by Laplume et al. (2008), the literature on stakeholder theory addressed five themes across multiple research fields, namely, stakeholder definition and salience, stakeholder actions and responses, firm actions and responses, firm performance and theory debates.

\subsection{Signaling Theory}

Aryati and Wibowo (2017) stated that signal theory discusses how companies should provide signals to users of financial statements, where these signals can be an information about the condition of the company to owners or other interested parties. Signal theory encourages firms to provide information to external parties. This is due to the occurrence of information asymmetry between management and external parties. In reducing information asymmetry, companies must disclose the information they have. Information that must be disclosed by companies is information about Corporate Social Responsibility. The company exercises the disclosure of Corporate Social Responsibility with the hope of being able to improve reputation and corporate value (Rustiarini, 2010).

\subsection{Corporate Social Responsibility}

Ocran (2011) stated that Corporate Social Responsibility (CSR) is a concept that requires practice in which corporate entities voluntarily integrate the good that received by companies both social and environmental in their business philosophy and operations. In Indonesia, the company's obligation to perform social responsibility is regulated in Article 1 Number 3 of Undang-Undang Nomor 40 Tahun 2007 related to Perseroan Terbatas (hereinafter referred to as the UU PT) by using the term Tanggung Jawab Sosial dan Lingkungan (TJSL) as a translation of the term Corporate Social Responsibility (CSR) to the context of the company in Indonesian society and defines it as company's commitment to participate in sustainable economic development in order to improve the quality of life and the useful environment, both for the company itself, the local community, and public in general.

\subsection{Stakeholder Theory and CSR}

82 
CSR is seen as "a process to integrate social, environmental, ethical, human rights and consumer concerns into their business operations with the aim of maximizing the creation of shared value for their owners/shareholders and for their other stakeholders and society at large" (European Commission, 2011). This conceptualization of CSR fits nicely with the stakeholder theory approach that views CSR as an extension of corporate governance, whereby a firm's duties extend beyond its shareholders to a broader group of stakeholders (Donaldson \& Preston, 1995; Freeman, 1984; Rowley \& Berman, 2000).

Previous empirical research viewed CSR activities under a single aggregated measure, there is a strong view that the different dimensions of CSR affect the firm in different ways and, thus, should be examined separately (Inoue \& Lee, 2011). and then, it has been argued that the multidimensionality of CSR can be better assessed through a stakeholder framework that evaluates firms manage their relationships with their stakeholders (Clarkson, 1995; Rowley \& Berman, 2000).

The stakeholder theory can be used with three different perspectives to study how stakeholder interests affect the characteristics of the firm and its multidimensional performance, among them namely descriptive (how the stakeholder theory concepts correspond to reality), instrumental (what are the configurations of managers' decisions regarding stakeholder interest in CSR activities and the outcomes?) and normative (how managers should deal with stakeholders' concerns regarding CSR activities and their motivations for it) (Donaldson \& Preston, 1995). The conceptualization of these perspectives requires the development of research models that are relevant.

\subsection{Corporate Governance}

Forum Corporate Governance on Indonesia (FCGI) defines corporate governance as a set of rules which manage the relationship between shareholders, managers, creditors, government, employees and other internal and external stakeholders that related to their rights and obligations. According to the Organization of Economic Cooperation and Development (OECD, 2004), corporate governance is a system in which a company or business entity is directed and supervised. Based on the description above, it can be concluded that the essence of corporate governance is a system and a set of regulations that manage the relationship of various stakeholders or in a narrow sense the relationship between shareholders, the board of commissioners and directors for the achievement of company's goal.

\subsection{Tax Avoidance}

Hanlon and Heitzman (2010) stated that tax avoidance can be interpreted as effective tax planning, namely reducing the tax expense through a scheme that has been regulated in taxation legislation and its nature does not cause disputes between taxpayers and tax authorities because it takes advantage of weaknesses 
in the taxation provisions of a country. Form of tax avoidance that is done legally is called tax management.

\subsection{The Relation of CSR and Tax Avoidance}

The paradox of promising social responsibility and ethical behaviour, on the one hand, and the dedication to tax avoidance and evasion, on the other hand, is criticised in the Sikka (2010) paper. According to the same source too, the problems usually originate from the lack of disclosure of information on tax issues in the financial reporting. Meanwhile according from Russel and Brock (2016) the explained that the topic of tax avoidance is sensitive and causes the feelings of anger and injustice, amongst other reasons because the expertise and availability of tax management options are available only to wealthy individuals and multinational companies. The paper from Preuss (2012) attempts to measures the relationship between CSR and tax avoidance. Nonetheless, the critical aspects of tax avoidance are acknowledged, as it seems clear that tax revenue is of enormous importance and an essential part of the functioning for the government and society. Therefore, Bird and Davis-Nozemack (2016) regard tax avoidance as a sustainability problem.

Bird and Davis-Nozemack (2016) said that the consequences of tax avoidance affect the environmental, social and economic aspects of the society, and thus demand a shift in values towards long-term responsibility. Fisher (2014) said that the adverse effects of tax avoidance affect not just the outside stakeholders but also the company itself because of potential misallocation of funds, reputational risks and the effects on the corporate culture. To support the Fisher's argument, Bird and Davis-Nozemack (2016) say that the firms have an obligation to conform to ethical and social demands from the society. This statement was based on a CSR point of view.

Some studies such as the paper by Muller and Kolk (2015) finds that firms with stronger CSR characteristics pay higher taxes. Similarly, Laguir et al. (2015) find that CSR and tax rate are positively related, and the relationship is mainly driven by social and economic factors of CSR. This intuitive argumentation follows the resource-based view, i.e., that firms use CSR to signal their performance.

Most empirical studies on the relationship of CSR and tax avoidance analyse it on a firm-level basis. The Jackson and Apostolakou's paper (2010) finds that CSR may take a substituting role for weaker institutions in liberal market economies. This approach is adopted to this analysis to gain some insight why there is a difference between the tax avoidance behaviour of firms from different countries.

The literature widely affirms that increased CSR is associated with lower effective tax rates. This supports the claims of Sikka $(2010,2013)$ accusing firms of acting "hypocrite". The research on tax avoidance and corporate governance finds evidence for an impact on value creation. Little is known how CSR affects the relationship between value creation and tax avoidance. It follows that an analysis of the value impact is worth further investigation in the context of CSR. 


\subsection{Hypothesis Development}

The relationship between corporate social responsibility disclosure and tax avoidance is based on theoretical legitimacy. According to Hidayati and Murni (2009), the concept of legitimacy shows company's responsibility to the public to be able to maintain its going concern. The higher the level of CSR disclosure of a company, the higher the company's reputation to the public. Watson (2011) in their research proved that companies that have higher CSR disclosure tend to be less aggressive in their tax avoidance practices compared to companies that have lower CSR disclosure. Lanis and Richardson (2012) research found that the higher the level of corporate social responsibility, the lower level of tax avoidance. Based on the description above, the first hypothesis in this study is as follows:

H1: Corporate social responsibility disclosure has a negative effect on tax avoidance

Salhi et al. (2019) found that if corporate governance has been performed well, companies tend are less likely to do tax avoidance. This is in line with research conducted by Minick (2010) who found that corporate governance mechanisms affect tax avoidance. In fact, the effect of increasing tax rates on government tax revenue will vary depending on the strength of corporate governance (Lee et al, 2015). Recent research conducted by Bayar et al. (2018) showed that stronger governance mechanisms can help companies reduce the negative consequences of tax avoidance. Based on the description above, the second hypothesis in this study is as follows:

H2: Corporate governance has a negative effect on tax avoidance.

Corporate social responsibility is one of the implementations of GCG which must be applied ethically for the sustainability of the company. If corporate governance has been properly performed, companies tend to not do tax avoidance (Salhi, 2019). Therefore, corporate governance can strengthen the negative effect of disclosure of corporate social responsibility on tax avoidance.

H3: Corporate Governance can moderate negative effect of corporate social responsibility disclosure on tax avoidance. 


\section{METHODOLOGY}

The companies sampled in this study are manufacturing companies in Indonesia that have been listed on the Indonesia Stock Exchange (IDX) in 2018. The dependent variable in this study is tax avoidance measured by the formula:

$$
\text { CASH ETR }_{i}=\frac{\sum_{i=1}^{N} \text { Cash Tax Paid }_{i t}}{\sum_{t=1}^{N}\left(\text { Pretax } \text { Income }_{i t}-\text { Special Items }_{i t}\right)} .
$$

The independent variable in this study is the score of corporate social responsibility disclosure measured using the performance indicators of the Global Reporting Initiative (GRI) 4.1.

$$
\mathrm{CSRD}=\frac{\sum \mathrm{X}}{\mathrm{N}}
$$

The moderation variable in this study is score of corporate governance measured by Asean CG Scorecard. The control variable in this study is size of the company, growth, ROA, and leverage. Hypothesis testing in this study will use direct equations through simple linear regression analysis and multiple linear regression analysis.

\section{RESULT AND DISCUSSION}

\subsection{Results of Sample Selection}

The population of this study were all manufacturing companies listed on the Indonesia Stock Exchange during 2018. The sample in this study was selected using the purposive sampling method. The list of companies sampled in this study can be seen in Appendix 1. Table 1. below shows a summary of the sample selection process used in the study.

Table 1. Selection of Research Sample

\begin{tabular}{lc}
\hline \multicolumn{1}{c}{ Sample Criteria } & Total \\
\hline Total of manufacturing companies listed on the IDX for the 2018 period & 177 \\
Manufacturing companies that publish annual reports for the 2018 period and can & $(39)$ \\
be accessed through www.idx.co.id. & $(28)$ \\
The company's annual report discloses corporate governance and corporate & $(10)$ \\
social responsibility activities & $(20)$ \\
Companies that issue financial statements in currencies other than Rupiah & $(6)$ \\
Companies that do not have an accumulated tax loss & 74 \\
\hline Companies with outlier data & \\
\hline
\end{tabular}




\subsection{Analysis of Descriptive Statistics}

Table 2. Descriptive Statistics

\begin{tabular}{llrrrr}
\hline & N & \multicolumn{1}{c}{ MAX } & \multicolumn{1}{c}{ MIN } & \multicolumn{1}{c}{ MEAN } & \multicolumn{1}{c}{ STD DEV } \\
\hline CSRD & 74 & 0,8352 & 0,0000 & 0,4018 & 0,2112 \\
CG & 74 & 92,7266 & 26,0329 & 68,1449 & 11,9292 \\
CETR & 74 & 1,3643 & 0,0008 & 0,3045 & 0,2183 \\
SIZE & 74 & 19,6582 & 11,9157 & 14,8176 & 16,6798 \\
GROWTH & 74 & 0,5854 & $-0,1476$ & 0,1338 & 0,1301 \\
ROA & 74 & 0,9210 & 0,0079 & 0,0952 & 0,1270 \\
LEV & 74 & 3,6093 & 0,0994 & 0,8430 & 0,7208 \\
\hline
\end{tabular}

Based on Table 2, the average value of the CSRD variable is 0.4018 . This means that the average value of the corporate social responsibility disclosure used as sample in this study is relatively low. In other words, manufacturing companies in Indonesia have not fully disclosed their corporate social responsibility in their annual reports. Meanwhile, the corporate governance variable has a standard deviation value of 11.9292 , with a mean or average of 68.1449 . The standard deviation is smaller than the mean, meaning that the corporate governance score in the sample companies is quite even or not very different. The tax avoidance variable has a minimum value of 0.0008 and a maximum value of 1.3643 , which means that the smaller amount of the tax avoidance means that the company is not doing tax avoidance. From the results of these descriptive statistics, it is known that the average value of tax avoidance in the sample studied is 0.3045 with a standard deviation of 0.2183 .

\subsection{Hypothesis Testing Results}

Based on the results of the regression analysis in table 3., it can be concluded that both corporate social responsibility and corporate governance have no effect on tax avoidance. Likewise, corporate governance cannot moderate the effect of corporate social responsibility on tax avoidance. 
Table 3. A Dependent Variable: CETR

\begin{tabular}{|c|c|c|c|c|c|c|}
\hline \multicolumn{2}{|c|}{ Model } & \multicolumn{2}{|c|}{$\begin{array}{l}\text { Unstandardized } \\
\text { Coefficients }\end{array}$} & \multirow{2}{*}{$\begin{array}{c}\begin{array}{c}\text { Standardize } \\
d \\
\text { Coefficients }\end{array} \\
\text { Beta }\end{array}$} & \multirow[t]{2}{*}{$\mathrm{t}$} & \multirow[t]{2}{*}{ Sig. } \\
\hline & & $B$ & Std. Error & & & \\
\hline \multirow{8}{*}{1} & (Constant) & 0.685 & 0.356 & & 1.924 & 0.059 \\
\hline & CSR & -0.203 & 0.722 & -0.196 & -0.281 & 0.780 \\
\hline & CG & -0.003 & 0.004 & -0.185 & -0.876 & 0.384 \\
\hline & SIZE & -0.015 & 0.019 & -0.118 & -0.795 & 0.430 \\
\hline & GRW & -0.137 & 0.200 & -0.082 & -0.688 & 0.494 \\
\hline & ROA & 0.671 & 0.193 & 0.391 & 3.474 & 0.001 \\
\hline & LEV & 0.032 & 0.035 & 0.105 & 0.900 & 0.371 \\
\hline & MOD & 0.003 & 0.009 & 0.254 & 0.318 & 0.751 \\
\hline
\end{tabular}

In testing the first hypothesis, it was found that corporate social responsibility had no effect on tax avoidance. This is in line with research by Preuss (2010) and Sikka (2010) showed companies that perform corporate social responsibility continue to avoid taxes. The higher the disclosure of corporate social responsibility, the higher the tax avoidance will be. In the Indonesian context, this occur closely related to tax incentives on corporate social responsibility in accordance with Undang-Undang No. 36 tahun 2008 concerning Perubahan Keempat UndangUndang Nomor 7 Tahun 1983 tentang Pajak Penghasilan dan Peraturan Pemerintah Nomor 93 tahun 2010, due to tax incentives for CSR expenditures in the form of tax deduction (is allowed companies expenditures related to CSR to calculate Taxable Income), so that the Income Tax Payable is smaller. With this tax reduction, tax incentives are expected to affect the relationship between corporate social responsibility and tax aggressiveness.

The result of testing the second hypothesis showed that corporate governance had no significant effect on tax avoidance in manufacturing companies listed on the Indonesia Stock Exchange in the 2018 period, where the significance value of 0.384 is greater than the significance level of 0.05 . Thus, $\mathrm{H} 1$ is rejected. Good corporate governance mechanisms cannot reduce the level of tax avoidance performed by management because tax avoidance will depend on the existence of other corporate governance mechanisms, such as stronger external monitoring (Desai and Dharmapala, 2006). One of the most important sources of outside monitoring is the external audit of the annual report $(\mathrm{Ng}, 1978)$. The reasons above also underlie the result of testing the third hypothesis in this study, where corporate governance cannot moderate the negative effect of corporate social responsibility on tax avoidance. 


\section{CONCLUSION}

This study aims to examine the effect of corporate social responsibility on tax avoidance, the effect of corporate governance on tax avoidance, and the effect of corporate social responsibility on tax avoidance with corporate governance as a moderating variable. The result showed that corporate social responsibility and corporate governance had no effect on tax avoidance. Likewise, corporate governance cannot moderate the effect of corporate social responsibility on tax avoidance.

The limitations of this study lie in the number of samples and years of observation as well as the corporate governance mechanism which is only measured by the Asean CG Scorecard. Future research is expected to increase the number of samples and the company sector to be studied and also extend the research time. In addition, we can add a corporate governance mechanism outside the Asean CG Scorecard so that it can represent the assessment of external parties of the company on the implementation of corporate governance.

\section{REFERENCE}

Bayar, O., Huseynov, F., and Sardarli, S., 2018. Corporate governance, tax avoidance, and financial constraints. Financial Management.

Christensen, J., and Murphy, R., 2004. The social irresponsibility of corporate tax avoidance: Taking CSR to the bottom line. Development, 47, 37-44.

Desai, M., and Dharmapala, D., 2006. Corporate tax avoidance and high-powered incentives. Journal of Financial Economics, 79, 145-179.

Dyreng, S.D., Hanlon, M., and Maydew, E.L. (2008). The effects of executives on corporate tax avoidance. The Accounting Review.

Freedman, J. 2003. Tax and corporate responsibility. Tax Journal, 695(2), 1-4.

Hanlon, M., dan Heitzman, S. 2010. A review of tax research. Journal of Accounting and Economics, 50(2-3), 127-178.

Lee, B.B., Dobiyanski, A., and Minton, S., 2015. Theories and empirical proxies for corporate tax avoidance. Journal of Applied Business and Economics.

Minnick, K.A., 2010. Do corporate governance characteristics influence tax management? . Journal of Corporate Finance, 16(5), 703-718.

$\mathrm{Ng}$, D.S., 1978. An information economics analysis of financial reporting and external auditing. The Accounting Review, 53, 910-920. 
Preuss, L., 2010. Tax avoidance and corporate social responsibility: You can't do both or can you?. Corporate Governance, 10(4).

Salhi, B., Riguen, R., Kachouri, M., and Jarboui, A., 2019. The mediating role of corporate social responsibility on the relationship between governance and tax avoidance: uk common law versus french civil law. Social Responsibility Journal.

Sikka, P., 2010. smoke and mirrors: CSR and tax avoidance. Accounting Forum, 153-168.

Watson, L., 2011. Corporate social responsibility and tax aggressiveness: an examination of unrecognized tax benefits. [pdf] Available at: www.ssrn.com. 